U.S. GEOLOGICAL SURVEY CIRCULAR 954

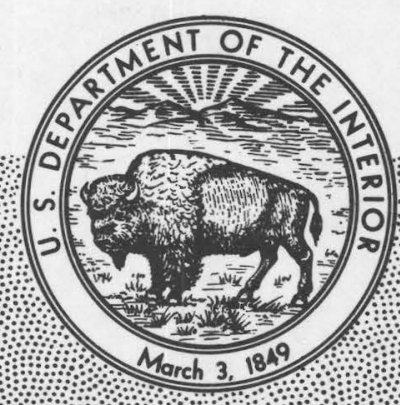

\title{
Core Index, A Numerical Core-Logging Procedure for Estimating Rock Quality
}





\section{Core Index, A Numerical Core-Logging Procedure for Estimating Rock Quality}

By John R. Ege

U.S.GEOLOGICAL SURVEY CIRCULAR 954

Procedures to be followed for rapid characterization of rock quality 
Department of the Interior DONALD PAUL HODEL, Secretary

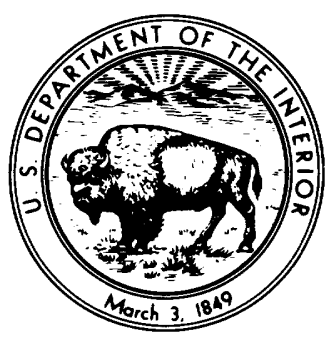

U.S. Geological Survey Dallas L. Peck, Director

Free on application to the Branch of Distribution, Books and Open-File Reports Section, U.S. Geological Survey, Federal Center, Box 25425, Denver, CO 80225 


\section{CONTENTS}

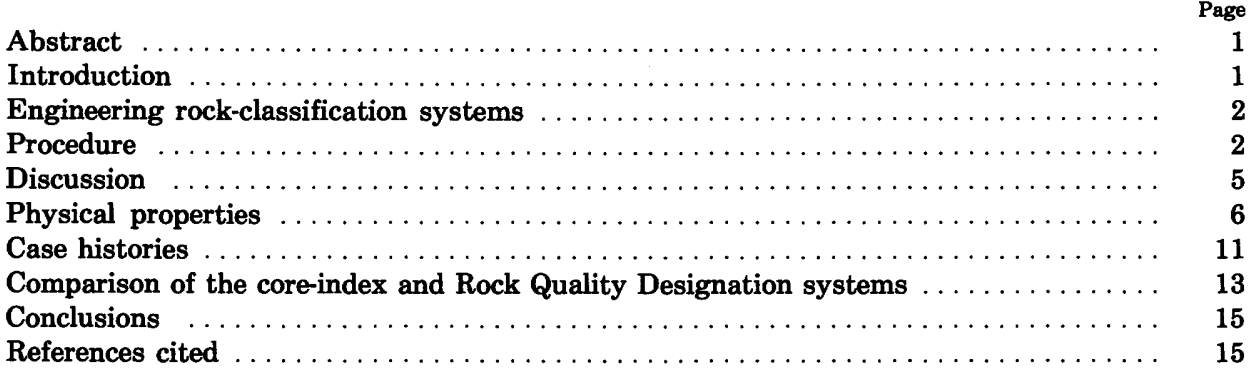

\section{ILLUSTRATIONS}

Figure $\quad$ 1. Sketch of the three logging categories used for calculating the core-index number $\ldots \ldots \ldots \ldots$

2. Sketch outlining method for accounting for effects of discontinuities in intact core $\ldots \ldots \ldots \ldots$

3. Photograph of oil shale core assigned a core-index value of $6 \ldots \ldots \ldots \ldots \ldots \ldots \ldots$

4. Photograph of oil shale core assigned a core-index value of $94 \ldots \ldots \ldots \ldots \ldots \ldots$

5. Graph of relative rock hardness and degree of weathering ranked against joint frequency for $732 \mathrm{~m}$

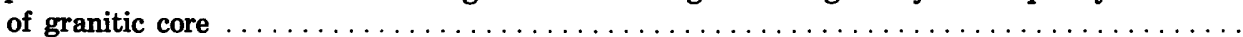

6-8. Graphs showing:

6. Porosity, dry-bulk density, laboratory compressional velocity, and laboratory shear velocity from granitic cores ranked against core-index numbers $\ldots \ldots \ldots \ldots \ldots \ldots \ldots \ldots \ldots$

7. Static Young's modulus, static shear modulus, static bulk modulus, and unconfined compressive strength from granitic cores ranked against core-index numbers .

8. Dynamic Poisson's ratio, dynamic Young's modulus, dynamic shear modulus, and dynamic bulk modulus from granitic cores ranked against core-index numbers $\ldots \ldots \ldots \ldots \ldots \ldots$

9. Profile of an exploratory borehole showing intervals of the borehole classified according to core-index

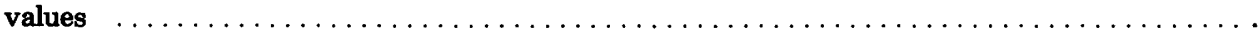

10-12. Graphs showing:

10. Core-index values from two adjacent vertical exploratory borings in oil shale, Piceance Creek Basin, Colorado $\ldots \ldots \ldots \ldots \ldots \ldots \ldots \ldots \ldots \ldots \ldots \ldots \ldots \ldots \ldots \ldots \ldots \ldots \ldots \ldots \ldots$

11. Comparison between a synthetic geologic plan constructed from horizontal borehole data using lithologic and core-index logging and a geologic plan mapped in a tunnel driven parallel to the

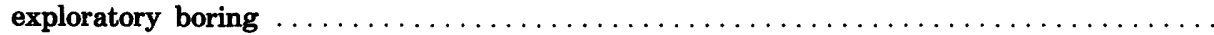

12. Relation between Rock Quality Designation and discontinuity frequency $\ldots \ldots \ldots \ldots \ldots \ldots$ 



\title{
Core Index, a Numerical Core-Logging Procedure for Estimating Rock Quality
}

\author{
By John R. Ege
}

\section{ABSTRACT}

The core index, a numerical core-logging procedure used by the U.S. Geological Survey since 1968 in engineering-geology projects at the Nevada Test Site and other locales, provides an objective means for estimating rock quality. The logging concept is based on the observation that rock-mass strength is reduced by discontinuities cutting the rock. The technique utilizes a combined discontinuity (joint, fault, bedding plane, contact, foliation, banding) frequency and core-loss measurement to calculate the core-index number. The core-index number ranks the rock from continuous to discontinuous (solid to fragmented) on a scale of 0 to 100 , the higher values indicating an increasing degree of fragmentation. The basic core-logging unit is a 10-cm (4-in.) length of core bounded by natural discontinuities. Three categories are used in logging core: lost core, core lost from the core barrel during drilling and assumed to be highly fragmented core less than $10 \mathrm{~cm} \mathrm{(4} \mathrm{in.)} \mathrm{in} \mathrm{length;}$ broken core, recovered core that is fragmented by natural discontinuities into pieces $10 \mathrm{~cm}$ (4 in.) or less in length; and intact core, recovered core greater than $10 \mathrm{~cm}$ (4 in.) in length. Intact core cut by discontinuities is related to the basic $10-\mathrm{cm}$ (4-in.) core unit by multiplying the number of discontinuities in a logged interval by $0.1 \mathrm{~m}$ for metric units or $0.3 \mathrm{ft}$ ( 4 in./12 in.) for English units.

The core-index (CI) number is calculated from:

$$
\mathrm{CI}=\frac{\begin{array}{c}
\text { Core loss }(\mathrm{m})+\text { Broken core }(\mathrm{m}) \\
+ \text { Number of discontinuities } \times 0.1(\mathrm{~m})
\end{array}}{\text { Drilled hole interval }(\mathrm{m})} \times 100
$$

\footnotetext{
Core loss (ft) + Broken core $(\mathrm{ft})$

$\mathrm{CI}=\frac{+ \text { Number of discontinuities } \times 0.3(\mathrm{ft})}{\text { Drilled hole interval }(\mathrm{ft})} \times 100$
}

Results of a study ranking physical property measurements of unconfined compressive strength, Young's modulus, shear modulus, bulk modulus, and compressional and shear velocities made on granitic cores against CI numbers showed decreasing values in the physical property measurements with increasing values of $C I$.

\section{INTRODUCTION}

Core index, a numerical core-logging procedure first developed at the Nevada Test Site (Nye County, Nev.) between 1965 and 1967 and since modified (Ege, 1968), has been in continuous use by the U.S. Geological Survey (USGS) on numerous engineering-geology projects. The corelogging procedure evolved from exploratory programs conducted by the USGS at the Nevada Test Site (NTS) that were aimed at assessing geologic conditions at sites of proposed mined and bored underground openings. The need to establish a relatively simple, objective, and precise means of describing lithologic and structural site conditions that could be used by engineers for site evaluation, design, and construction became very apparent during the early phases of the exploration program.

The core index, a modified discontinuityfrequency percentage, was first applied to granitic cores taken from the Climax Stock at the NTS and later applied to volcanic and sedimentary rocks at various NTS sites. The logging procedure is based on the observation that rock-mass strength is reduced by discontinuities cutting the rock and that generally the greater the number of discontinuities per volume of rock mass, the less competent the rock is as an engineering material.

Goodman (1976, p. 40) described a single discontinuity as comprising two mating surfaces and a space or filling. Obert and Duvall (1967, p. 310312) stated that a discontinuity is a plane of weakness in the rock which, under applied stress, has the potential of failing before failure occurs in the intact rock. Examples of geologic discontinuities are joints, fractures, faults, foliation, schistosity, banding, bedding contacts, and cleavage.

The CI ranks the rock from 0 "excellent" to 100 "very poor," where 0 signifies continuous sound core and 100 totally fragmented core over the drilled interval. The CI is, therefore, a measure of discontinuities, increasing in value as the number of discontinuities increases over the drilled interval. The logging procedure has removed some of the subjective structural descriptions of cores made by individuals examining core from borings and has established a standard by which an estimate of rock quality can be made. The procedure has been applied to a variety of rock types at the 
NTS and other locales, and an extensive body of core information has been gathered by USGS personnel.

\section{ENGINEERING ROCK-CLASSIFICATION SYSTEMS}

A number of workers have established systems that attempt to standardize and quantify descriptions of rock material and rock masses (Terzaghi, 1946; Deere, 1963; Coates, 1964; Deere and others, 1967; Barton and others, 1974; Bieniawski, 1974). Information used by these systems to rank the rock include number, spacing and orientation of discontinuities, roughness of discontinuity surfaces, type of material filling discontinuities, degree of alteration of rock, groundwater conditions, depth of rock mass, and strength of rock. These systems range from those that require many parameters and provide a detailed engineering analysis of rock conditions to those that examine a few core parameters and provide a rapid estimate of rock quality. The former are elaborate, informative design tools, requiring considerable effort and time. For example, Barton and others (1974) and Bieniawski (1974) utilize numerous geologic, hydrologic, and rock parameters that provide detailed information for design and construction of underground openings such as tunnels. The latter are fast, simple exploratory tools, such as the Rock Quality Designation (RQD) (Deere, 1963; Deere and others, 1967) which uses a single measure of discontinuity spacing in determining estimates of rock quality.

\section{PROCEDURE}

Conceptually, the CI logging technique rests on a combined measurement of discontinuities, core loss, and broken core (fig. 1). A core length of $10 \mathrm{~cm}$ (4 in.) separated by natural discontinuities is the basic core unit; all measurements are based on this unit length of core. Intact core refers to core pieces whose lengths are greater than $10 \mathrm{~cm}$ (4 in.). Core loss is defined as rock so fragmented by natural discontinuities or crushing that its pieces cannot be retained in the core barrel. Broken core is determined by measuring all increments of core separated by natural discontinuities into pieces less than $10 \mathrm{~cm}(4 \mathrm{in}$.) in size.

First, the recovered core is laid out in a core tray or in core boxes, and the length of borehole to be logged is determined. The selected hole length can be some convenient unit, for example, $10 \mathrm{~m}(30 \mathrm{ft}$ ),

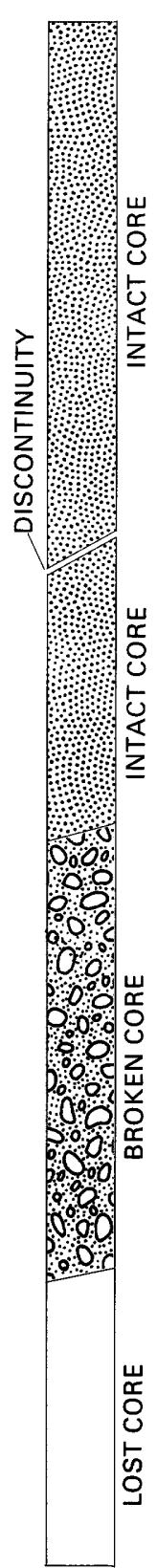

FIGURE 1.-The three logging categories used for calculating the core-index number. Lost core, core not recovered from drilling. Broken core, core fragmented by natural discontinuities into pieces $10 \mathrm{~cm} \mathrm{(4} \mathrm{in.)} \mathrm{or} \mathrm{less} \mathrm{in} \mathrm{length.} \mathrm{Intact} \mathrm{core,} \mathrm{core}$ recovered in lengths greater than $10 \mathrm{~cm}(4 \mathrm{in}$.$) .$

or perhaps the length of the core barrel. Second, the total amount of recovered core is measured and recorded, subtracted from the drilled hole length, and noted as core loss in terms of meters (feet). In some instances core loss may be caused by rock grinding during drilling and may not be the result of natural processes. The core logger should be aware of this possibility and correct measurements of core loss related to drilling procedures. Third, the total increments of broken core are recorded as length of broken core in meters (feet). Again, care 
must be taken to include only core fragments cut by natural discontinuities and not fractures created by drilling or handling. Fourth, a count of discontinuities cutting and separating the intact core into discrete pieces is recorded.

Natural discontinuities are potential planes of weakness and are accounted for in the CI system. The lengths of the intact core pieces formed by discontinuities are referenced to the basic $10-\mathrm{cm}$ (4-in.) logging unit. Thus, if $1 \mathrm{~m}$ of core is cut perpendicularly by 10 equally spaced discontinuities (excluding the butt end), the core will be divided into ten $10-\mathrm{cm}$ core lengths. This configuration would then be equivalent to $1 \mathrm{~m}$ of broken core. If $1 \mathrm{~m}$ of core is cut by four discontinuities, then a maximum of $0.4 \mathrm{~m}$ of $10-\mathrm{cm}$ pieces could exist, assuming a 10-cm discontinuity spacing in sequence. This then would be comparable to $0.4 \mathrm{~m}$ of broken core. Multiplying the number of discontinuities counted in a specified length of intact core by $0.1 \mathrm{~m}$ is a means of including the effect of all discontinuities, regardless of orientation, by the logging procedure (fig. 2). For the unique case in which a discontinuity cuts a piece of core parallel to its axis, the discontinuity is counted as a single discontinuity in the calculation.

Similarly, when using the English system of measurements, $1 \mathrm{ft}$ of intact core is cut into 4 -in. pieces by three equally spaced discontinuities. Multiplying the number of discontinuities contained in a specified length of core by $0.3 \mathrm{ft}(4 \mathrm{in} . /$ 12 in. $\times 1 \mathrm{ft}$ ) will again arbitrarily equate the intact core discontinuity count to a comparable length of broken core (fig. 2).

The following examples illustrate the use of the core-logging procedure and calculation of the coreindex value, which is the designated value relating the structural properties of the core to rock quality. Rock type: Granite

Total length of borehole: $40 \mathrm{~m}$

Specified borehole logging unit: $10 \mathrm{~m}$

Hole

\begin{tabular}{|c|c|c|c|}
\hline $\begin{array}{l}\text { interval } \\
\text { (m) }\end{array}$ & $\begin{array}{c}\text { Core loss } \\
\text { (m) }\end{array}$ & $\begin{array}{c}\text { Broken core } \\
(\mathrm{m})\end{array}$ & $\begin{array}{c}\text { Discontinuity } \\
\text { count }\end{array}$ \\
\hline $0-10$ & 2.0 & 1.7 & 22 \\
\hline $10-20$ & 1.6 & .9 & 16 \\
\hline $20-30$ & 1.1 & .7 & 12 \\
\hline $30-40$ & .7 & .3 & 4 \\
\hline
\end{tabular}

Core index (CI) (in percent)

Core loss $(\mathrm{m})+$ Broken core $(\mathrm{m})$

+ Number of discontinuities

$\mathrm{CI}=\frac{\times 0.1(\mathrm{~m})}{\text { Drilled hole interval }(\mathrm{m})} \times 100$
Hole

interval

(m)

$\underline{\text { CI }}$

$0-10 \quad C I=\frac{\begin{array}{l}2.0 \mathrm{~m}+1.7 \mathrm{~m} \\ +22 \times 0.1 \mathrm{~m}\end{array}}{10 \mathrm{~m}} \times 100=59$

$10-20 \mathrm{CI}=\frac{\begin{array}{c}1.6 \mathrm{~m}+0.9 \mathrm{~m} \\ +16 \times 0.1 \mathrm{~m}\end{array}}{10 \mathrm{~m}} \times 100=41$

$20-30 \quad \mathrm{CI}=\frac{\begin{array}{l}1.1 \mathrm{~m}+0.7 \mathrm{~m} \\ +12 \times 0.1 \mathrm{~m}\end{array}}{10 \mathrm{~m}} \times 100=30$

$30-40 \quad \mathrm{CI}=\frac{\begin{array}{c}0.7 \mathrm{~m}+0.3 \mathrm{~m} \\ +4 \times 0.1 \mathrm{~m}\end{array}}{10 \mathrm{~m}} \times 100=14$

Rock type: Ash-fall tuff

Total length of borehole: $160 \mathrm{ft}$

Specified borehole logging unit: $20 \mathrm{ft}$

Hole

interval Core loss Broken core Discontinuity

\begin{tabular}{|c|c|c|c|}
\hline (ft) & (ft) & (ft) & count \\
\hline $0-20$ & 3.0 & 1.0 & 4 \\
\hline $20-40$ & 2.7 & .8 & 6 \\
\hline $40-60$ & .9 & .4 & 3 \\
\hline $60-80$ & .9 & .3 & 1 \\
\hline $80-100$ & 1.3 & .7 & 2 \\
\hline $100-120$ & 3.3 & 2.1 & 10 \\
\hline $120-140$ & 2.1 & 1.6 & 8 \\
\hline $140-160$ & .8 & .7 & 3 \\
\hline
\end{tabular}

Core index (CI) (in percent)

Core loss $(\mathrm{ft})+$ Broken core $(\mathrm{ft})$

+ Number of discontinuities

$\mathrm{CI}=\frac{\times 0.3(\mathrm{ft})}{\text { Drilled hole interval }(\mathrm{ft})} \times 100$

Hole

interval

(ft)

$0-20 \quad \mathrm{CI}=\frac{\begin{array}{c}3.0 \mathrm{ft}+1.0 \mathrm{ft} \\ +4 \times 0.3 \mathrm{ft}\end{array}}{20 \mathrm{ft}} \times 100=26$

$20-40 \mathrm{CI}=\frac{\begin{array}{c}2.7 \mathrm{ft}+0.8 \mathrm{ft} \\ +6 \times 0.3 \mathrm{ft}\end{array}}{20 \mathrm{ft}} \times 100=26$ 


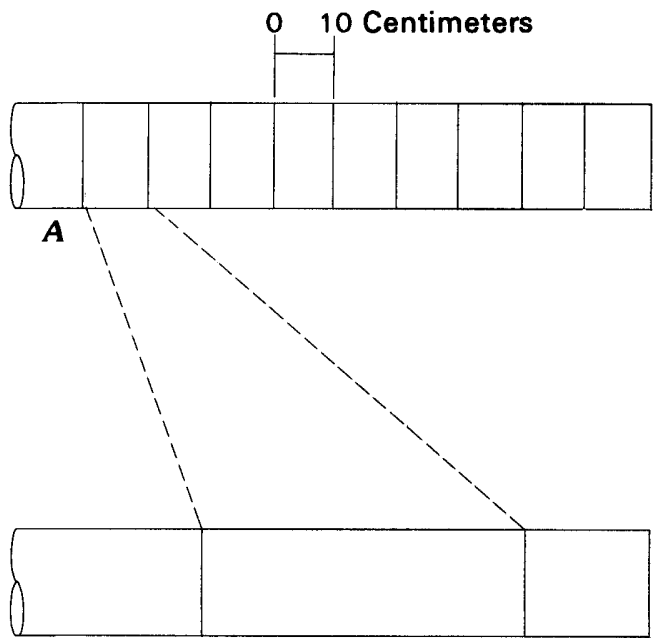

B

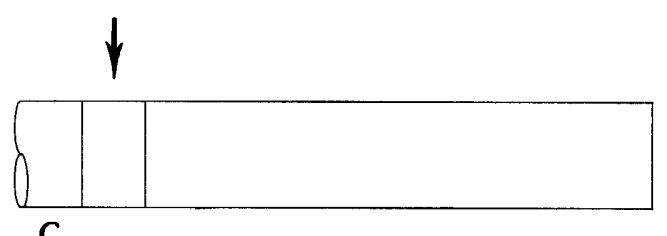

C
10 Discontinuities $=$ 1 meter Broken Core

2 Discontinuites $\simeq$ 0.2 meters Broken Core

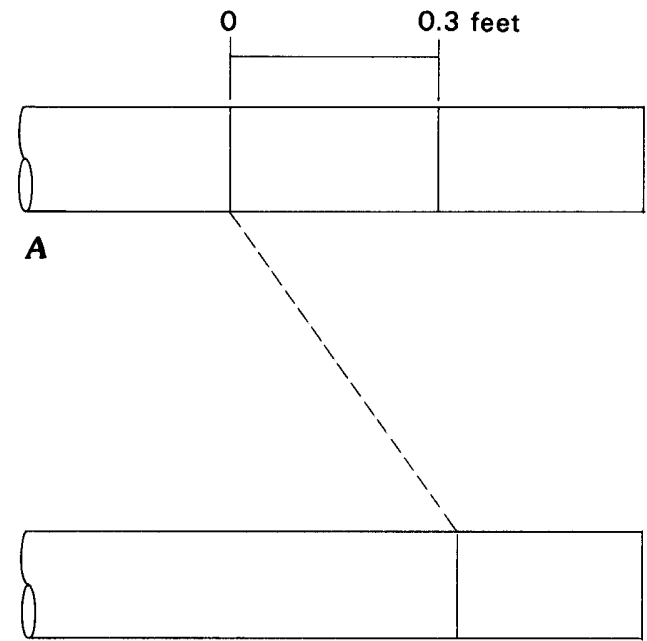

B

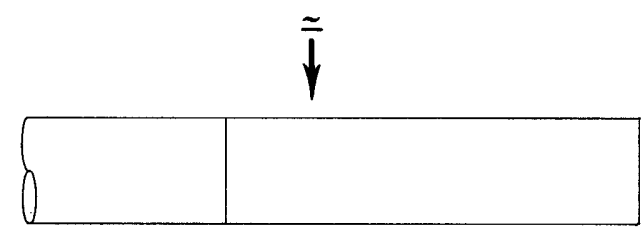

1 Discontinuity $=$ 0.3 feet Broken Core

\section{0}

FIGURE 2.-Method for accounting for effects of discontinuities in intact core. The basic core unit, broken core, used in calculating the core-index number is a 10-cm (4-in.) core length bounded by natural discontinuities. To account for the effects of discontinuities separating intact core (core lengths greater than $10 \mathrm{~cm}$ (4 in.)) and relate the intact core to broken core, multiply the number of discontinuities cutting the intact core by $0.1 \mathrm{~m}(0.3 \mathrm{ft})$. 
Hole

interval

(m)

$$
\begin{aligned}
40-60 \mathrm{CI}=\frac{\begin{array}{c}
0.9 \mathrm{ft}+0.4 \mathrm{ft} \\
+3 \times 0.3 \mathrm{ft}
\end{array}}{20 \mathrm{ft}} \times 100=11 \\
60-80 \mathrm{CI}=\frac{\begin{array}{c}
0.9 \mathrm{ft}+0.3 \mathrm{ft} \\
+1 \times 0.3 \mathrm{ft}
\end{array}}{20 \mathrm{ft}} \times 100=8 \\
80-100 \mathrm{CI}=\frac{\begin{array}{c}
1.3 \mathrm{ft}+0.7 \mathrm{ft} \\
+2 \times 0.3 \mathrm{ft}
\end{array}}{20 \mathrm{ft}} \times 100=13 \\
100-120 \mathrm{CI}=\frac{\begin{array}{c}
3.3 \mathrm{ft}+2.1 \mathrm{ft} \\
+10 \times 0.3 \mathrm{ft}
\end{array}}{20 \mathrm{ft}} \times 100=42 \\
120-140 \mathrm{CI}=\frac{\begin{array}{c}
2.1 \mathrm{ft}+1.6 \mathrm{ft} \\
+8 \times 0.3 \mathrm{ft}
\end{array}}{20 \mathrm{ft}} \times 100=31 \\
140-160 \mathrm{CI}=\frac{\begin{array}{c}
0.8 \mathrm{ft}+0.7 \mathrm{ft} \\
+3 \times 0.3 \mathrm{ft}
\end{array}}{20 \mathrm{ft}} \times 100=12
\end{aligned}
$$

The examples of Calculations presented in the previous section illustrate that increasing values of CI have a corresponding increase in discontinuites contained in the core. On a scale of $0-100$, the higher CI values designate a very fragmented rock and, therefore, can be related to a less competent engineering material (figs. 3 and 4). In fact, observations based on numerous site-evaluation projects made by the author and others have produced a rule of thumb which states that rock having CI values in general greater than 80 and in many cases greater than 50 has proven to be a difficult construction medium, and the rock so classified has been designated as poor or problem rock. Estimates of rock quality determined from ranges of $\mathrm{CI}$ values are shown below. These designations are based on field observations.

\begin{tabular}{cl}
\hline Core index & Rock quality \\
\hline $0-10$ & Excellent \\
$10-30$ & Good \\
$30-50$ & Fair \\
$50-80$ & Poor \\
$80-100$ & Very poor \\
\hline
\end{tabular}

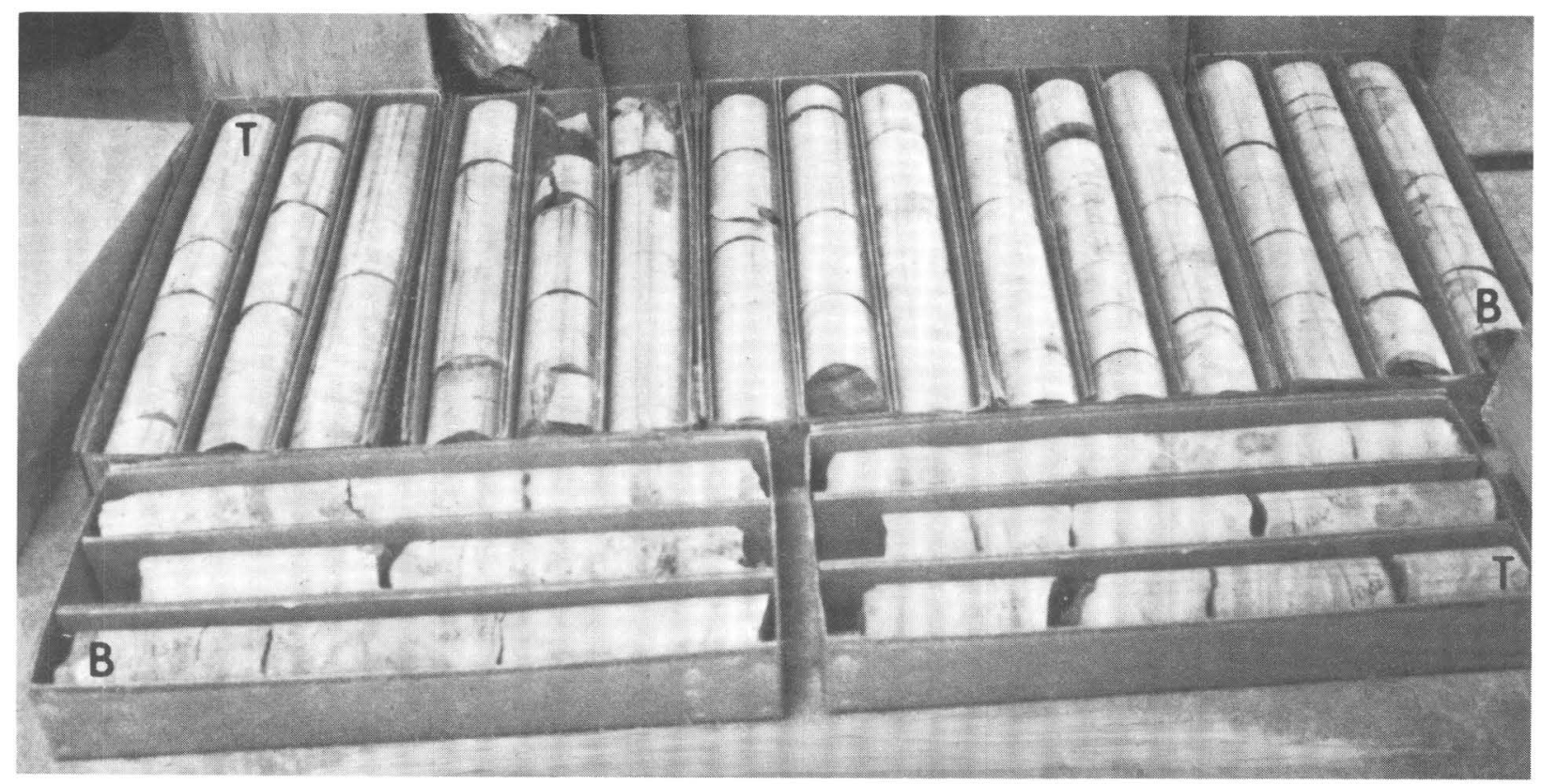

FIGURE 3.-Example of oil shale core assigned a core-index value of 6 over borehole logging interval of $15 \mathrm{~m}(50 \mathrm{ft})$. 


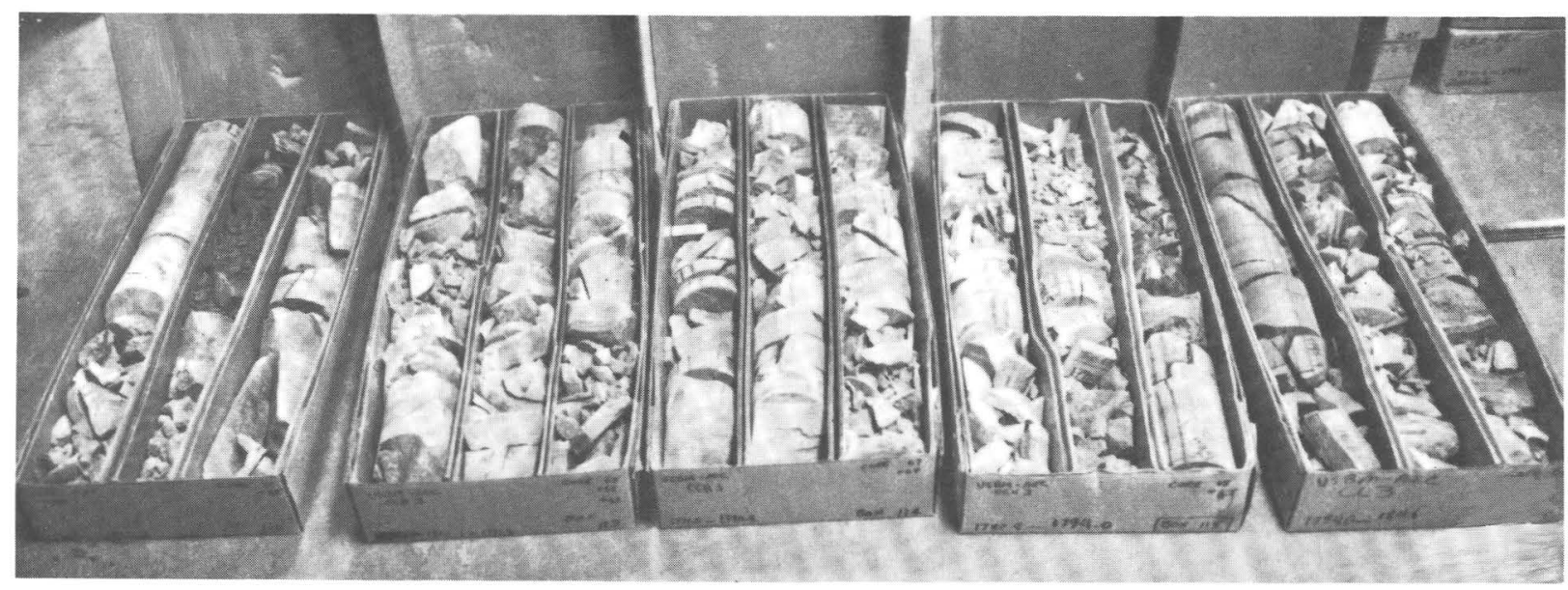

Figure 4.-Example of oil shale core assigned a core-index value of 94 over borehole logging interval of $15 \mathrm{~m}(50 \mathrm{ft}$ ).

Examples of rock types on which the CI procedure has been applied by USGS investigators include granite, ash-fall and ash-flow tuff, rhyolite and basalt, argillite and shale, limestone and dolomite, sandstone, quartzite, granite gneiss, and amphibolite schist.

In 1968 , in a study conducted at the NTS, I qualitatively examined $732 \mathrm{~m}(2,400 \mathrm{ft})$ of granitic core for degree of weathering and relative hardness with respect to number of joints (the dominant discontinuity) contained in core recovered over 15-m (50-ft) lengths of bored hole. I ranked the properties of degree of weathering and relative hardness against joint frequency (joint per meter or foot) measured in the core over the $15-\mathrm{m}$ or 50 $\mathrm{ft}$ intervals (fig. 5). The results of the comparison showed a decrease in hardness and an increase in weathering with concurrent increase in joint frequency. An observable change in both the relative hardness and degree of weathering was apparent at a frequency of 10 joints per meter (three joints per foot) or at an approximate joint spacing of $10 \mathrm{~cm}$ (4 in.). It was on the basis of this information obtained from the granitic cores that the 10-cm (4-in.) core length was selected as the basic core unit used for the logging procedure and, subsequently, applied to other rock types.

All geologic discontinuities have the capability of separating or failing along their respective planes and, therefore, are sources of weakness. Discontinuities will vary, however, with rock type, and the dominant forms of discontinuities contained in a particular rock mass depend on its properties, history, and geometry. Granite, a brittle igneous rock, can split along joint planes; shale, a low modulus sedimentary rock, can separate along bedding planes; and basalt, a brittle volcanic rock, can fail along both flow banding and joint planes. Judgment must be used when examining core, and discontinuities in all their forms should be considered and recorded in terms of their effects on the strength of the rock mass.

\section{PHYSICAL PROPERTIES}

Granitic cores were selected from intervals of core taken from the Climax Stock, NTS, ranked according to CI values, and submitted to the USGS laboratory in Denver, Colo., for physical property tests. The three CI groupings chosen ranged from good to poor rock, or $\mathrm{CI}=0-30$ percent, 31-60 percent, and 61-100 percent. Tests were conducted on 31-42 cores for each of the following 12 properties: porosity, drybulk density, static Young's modulus, static shear modulus, static bulk modulus, unconfined compressive strength, compressional velocity, shear velocity, dynamic Poisson's ratio, dynamic Young's modulus, dynamic shear modulus, and dynamic bulk modulus. The averages and ranges of the results, plotted for each test (figs. 6-8), show a decrease in property value as CI values increase with the exception of porosity; porosity becomes greater with increasing CI.

The physical property test results made on the granitic cores indicate that in addition to a reduction in structural continuity of the rock mass, there is an accompanying lowering of laboratory physical property values. For example, the means of unconfined strength values decreased about 50 percent from 206.8 $\mathrm{MPa}\left(30,000 \mathrm{lbf} / \mathrm{in}^{2}\right)$ in the 049 percent group to $103.4 \mathrm{MPa}\left(15,000 \mathrm{lbf} / \mathrm{in}^{2}\right)$ in the 80-100 percent group, and the means of compressional velocity decreased about 13 percent $(5,608-4,877 \mathrm{~m} / \mathrm{s}$ or $18,400-16,000 \mathrm{ft} / \mathrm{s})$ within the same CI categories for the granitic rock samples. Thus the CI system may have application in 


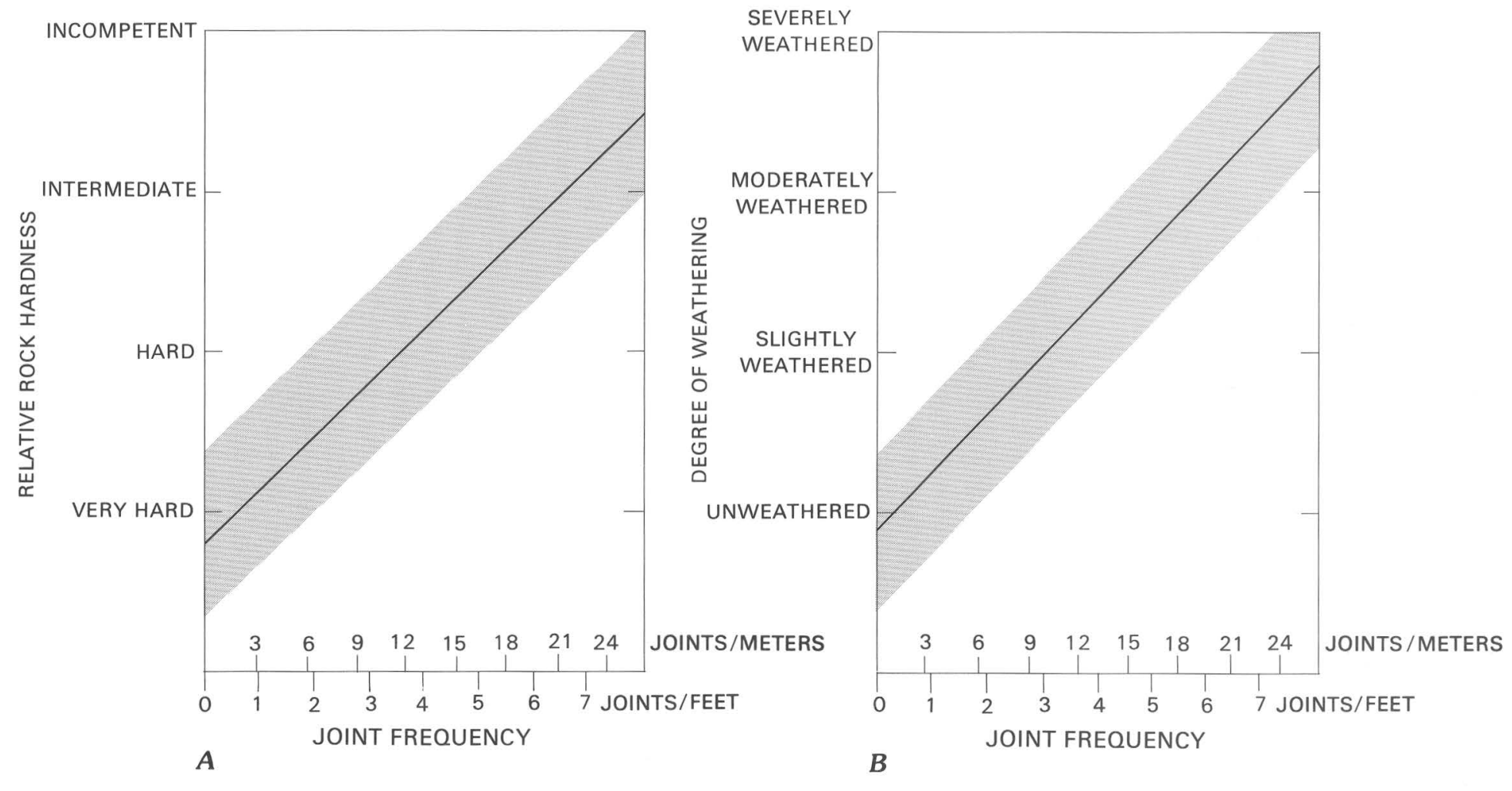

FIGURE 5.-Relative rock hardness and degree of weathering ranked against joint frequency (joints per meter) for $732 \mathrm{~m}(2,400 \mathrm{ft})$ of granitic core. $A$, Relative rock hardness was estimated by an iron-nail scratch test. $B$, Degree of weathering was estimated from visual examination of the amount of feldspar alteration in the granite. (Modified from Ege, 1968.) 

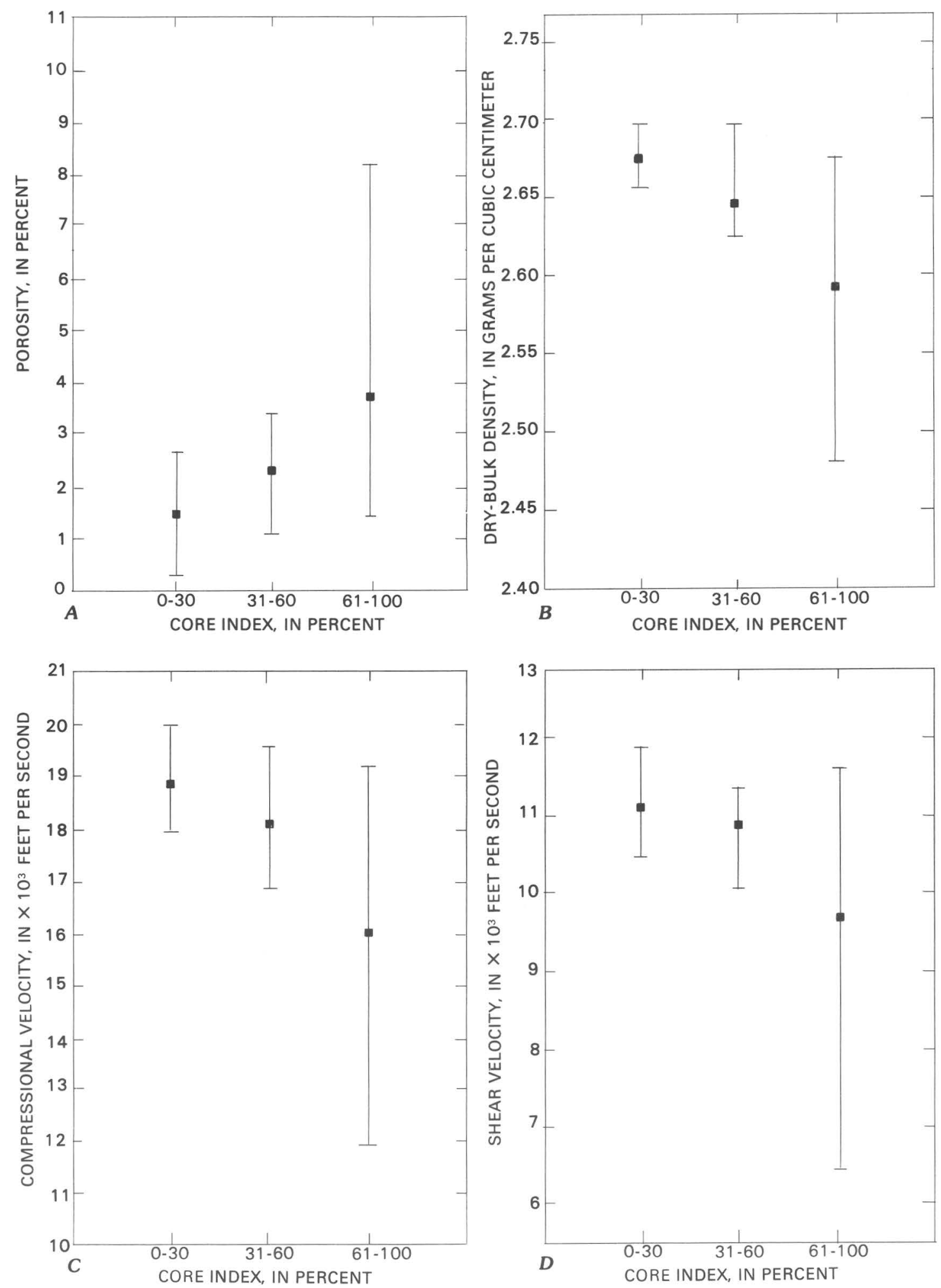

Figure 6.-Porosity (A), dry-bulk density $(B)$, laboratory compressional velocity $(C)$, and laboratory shear velocity $(D)$ from 42 samples of granitic cores ranked against core-index numbers. Minimum, maximum, and average of physical properties plotted for the following core-index groups: $0-30,31-60,61-100$. 

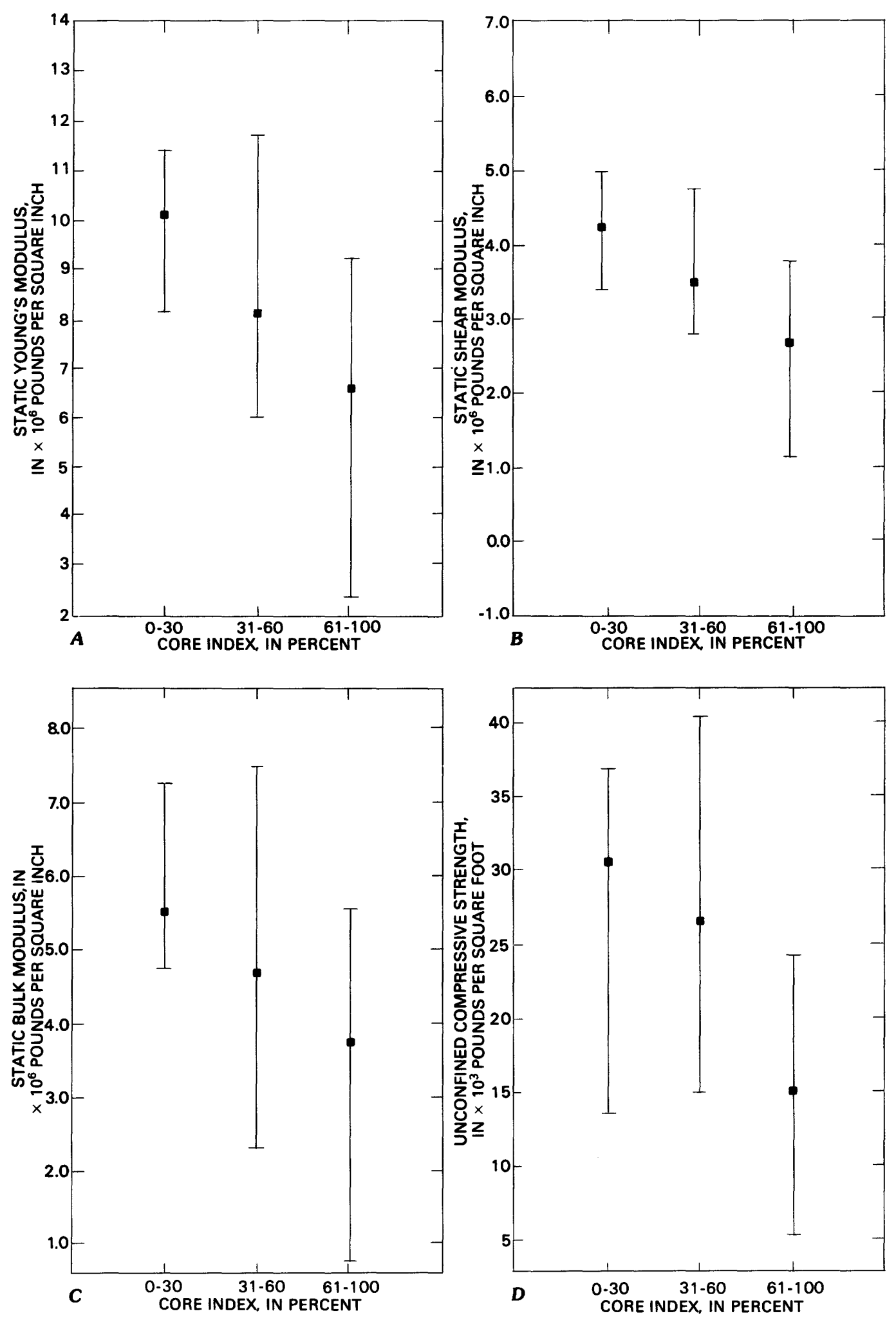

Figure 7.-Static Young's modulus $(A)$, static shear modulus $(B)$, static bulk modulus $(C)$, and unconfined compressive strength $(D)$ from granitic cores ranked against core-index numbers. Minimum, maximum, and average of physical properties plotted for the following core-index groups: 0-31, 30-60, 61-100. 

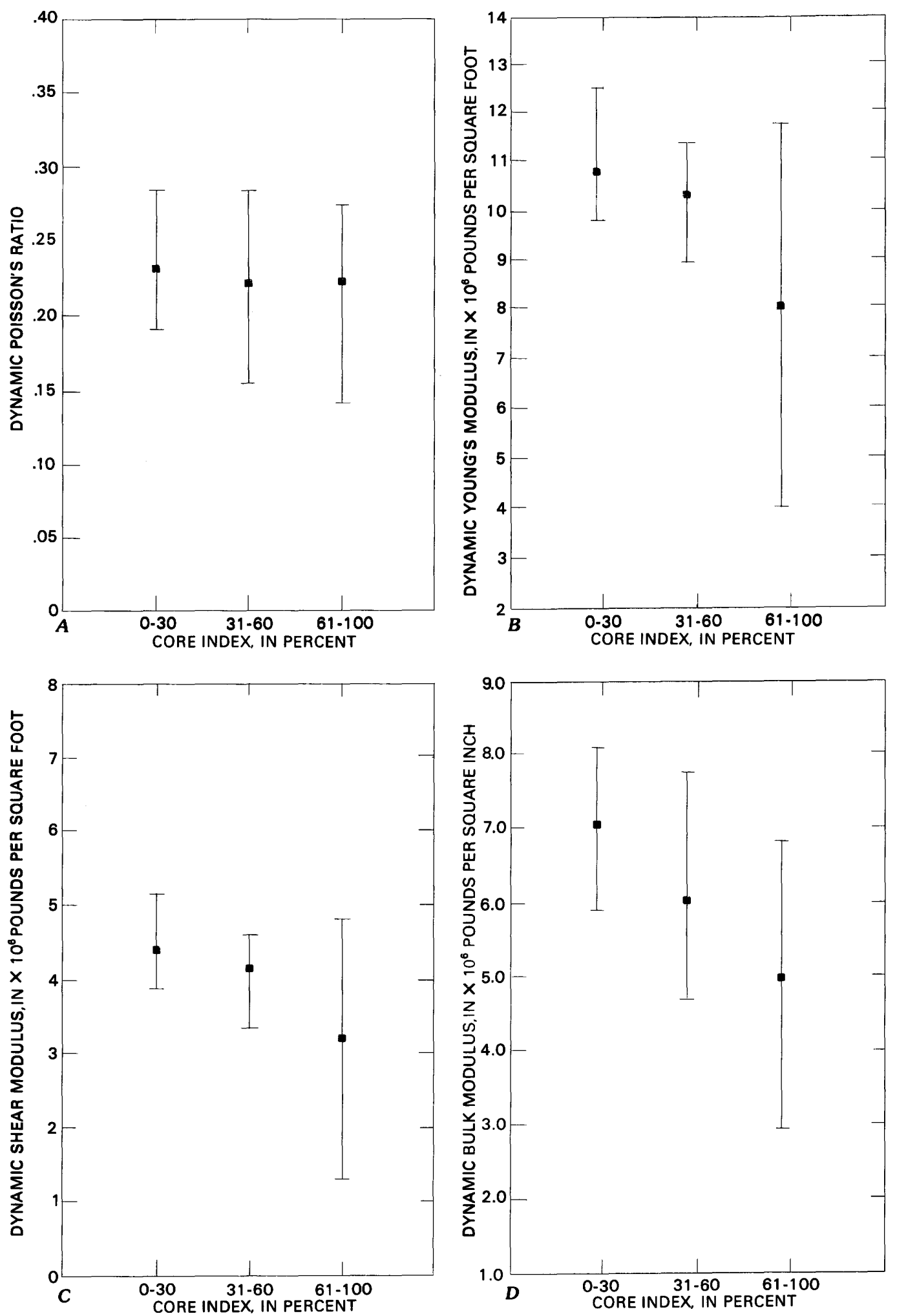

Figure 8.-Dynamic Poisson's ratio $(A)$, dynamic Young's modulus $(B)$, dynamic shear modulus $(C)$, and dynamic bulk modulus $(D)$ from granitic cores ranked against core-index numbers. Minimum, maximum, and average of physical properties plotted for the following core-index groups: 0-30, 31-60, 61-100. 
estimating changes in granitic rock properties (and possibly those of other lithologies) resulting from the effects of discontinuites.

\section{CASE HISTORIES}

The CI method was used to evaluate a construction site at the NTS in the Climax Stock, a jointed granodiorite-porphyritic quartz monzonite intrusive body. Design criteria for a $21-\mathrm{m}$ (70-ft) diameter, hemispherical-shaped chamber constructed in granitic rock required that the structure be mined in competent high-strength rock at a depth of at least $91 \mathrm{~m}(300 \mathrm{ft})$ (Ege, 1983). The limiting factor for siting the chamber was to find as continuous a rock mass as possible at the prescribed depth. The site-appraisal program, in addition to geologic mapping, included three exploratory boreholes inclined in such a way that the borings would pass through the proposed hemisphere at three different levels. The recovered cores from the three borings were structurally analyzed using the CI method and a location chosen that met design requirements. A profile of one of the exploratory holes (fig. 9) shows the plot of CI numbers along the alignment of the boring and the recommended location for the proposed chamber. The site was selected in a zone of low CI numbers $(11<\mathrm{CI}<36)$ which designated a volume of rock containing relatively few discontinuities. Construction of the hemispherical chamber at the selected location was completed successfully in a region of structurally competent rock and confirmed the prediction of suitable rock for mining the uniquely shaped opening.

The CI method was also used in determining a site for a mine in northwestern Colorado. Specifications developed by the U.S. Bureau of Mines for an experimental shaft and mine for testing mining techniques in the oil shale of the Piceance Creek Basin of northwestern Colorado called for a carefully designed geologic and hydrologic evaluation of several potential sites (Ege and others, 1978). An acceptable site that would be typical of conditions expected to be encountered by commercial mining of oil shale had to include the following stratigraphic and structural sequences: (1) an overburden thickness of $245-365 \mathrm{~m}$ (800-1,000 ft) to the top of the Mahogany zone, an upper oilshalebearing unit; (2) a thickness of about $120 \mathrm{~m}$ (400 ft) of the leached saline zone, an evaporite unit thickening toward the center of the basin which has

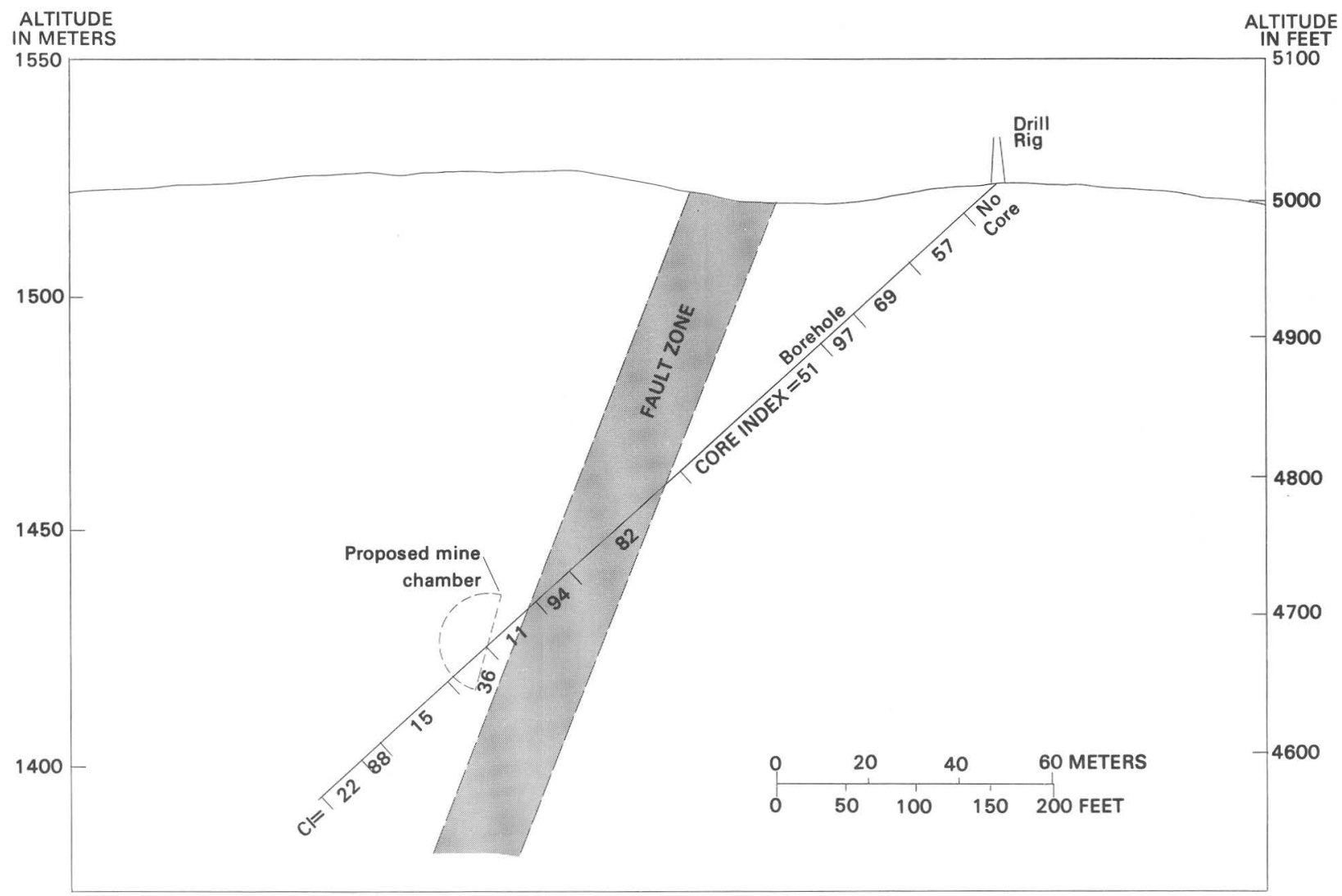

FIGURE 9.-Exploratory borehole showing intervals classified according to core-index values (numbered). Boring penetrates granitic rock of the Climax Stock, Nevada Test Site, in which location of a large hemispheric chamber was determined, in part, from the core analysis. Dashed lines bound possible fault zone. 
undergone dissolution by ground water and represents a structurally weak zone lying below the Mahogany zone; (3) a continuous oil-shale zone below the leached zone at least 150-300 m (500$1,000 \mathrm{ft}$ ) thick and averaging $70 \mathrm{~L} / \mathrm{t}$ (20 gal/short ton) of in-place shale oil; and (4) no areas containing major fault or fracture systems. Two exploratory cores, taken from boreholes (C-171 and C-34) drilled in one of the potential mine sites, were logged by the USGS using the CI procedure. The

Surface altitude $=1,937 \mathrm{~m}(6,356 \mathrm{ft})$

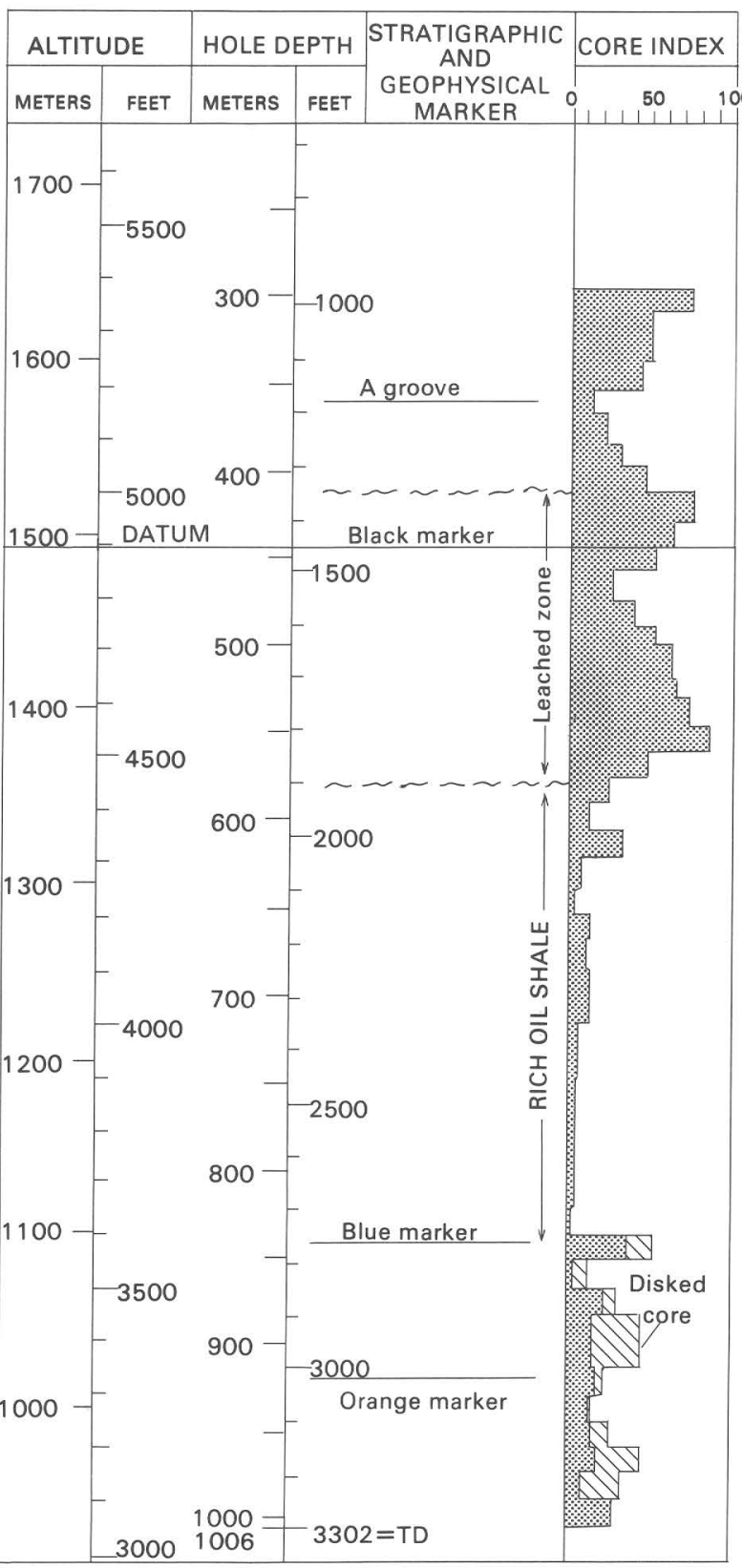

A results of the core logging, presented in figure 10 using the local geophysical "Black" marker as the datum level, document the areally discontinuous and vuggy nature of the evaporite, caused by dissolution and resulting in high CI values ( $>50$ percent). Two other structural intervals appear on both core logs, a fractured zone lying immediately above the leached evaporites and an interval of core near the bottom of the hole that readily separates into thin disks.

Surface altitude $=1,830 \mathrm{~m}(6,003 \mathrm{ft})$

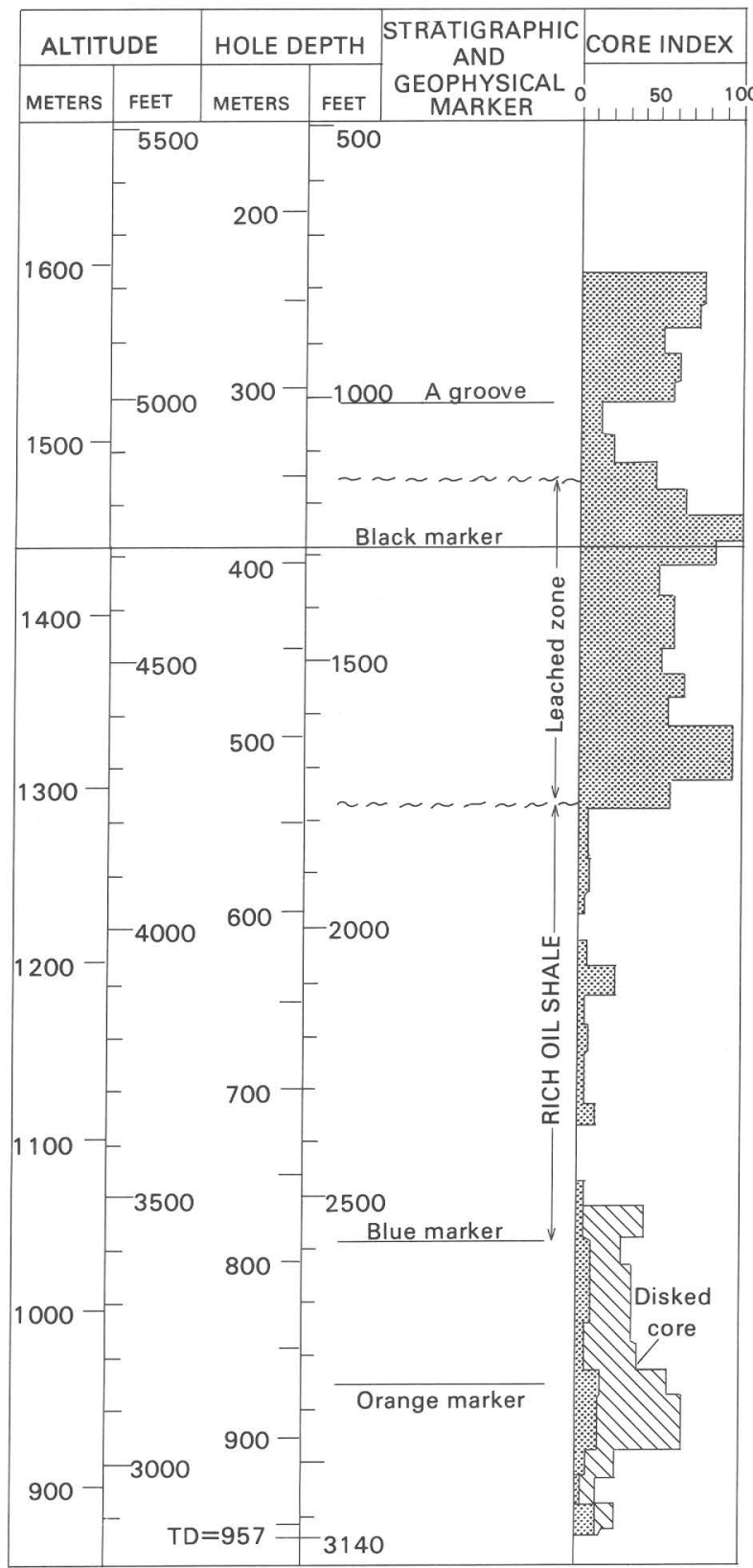

B

FIgURE 10.-Core-index values from two adjacent vertical exploratory borings $(A$ and $B$ ) in oil shale, Piceance Creek Basin, Colorado. The high core-index values locate the pervasive saline "leached zone" above a lower rich oil-shale zone. The low core-index values below the saline zone indicate a continuous interval of intact rock. See figures 3 and 4 . Disked core at the bottom of boring represents core separating into 1- to 10-cm-wide fragments (disks) at right angles to the core axes. 
In constructing a 609-m (2,000-ft) long tunnel complex in zeolitized ash-fall tuff $396 \mathrm{~m}(1,300 \mathrm{ft})$ below Rainier Mesa at NTS, the CI method was also used. Prior to construction, a 472-m (1,400$\mathrm{ft})$ horizontal borehole was drilled parallel to the proposed tunnel alignment to forecast rock properties and construction conditions, a standard procedure for tunnel design at the NTS (Fairer and others, 1979). The recovered core from the exploratory boring was logged for lithology and CI numbers. A synthetic geologic plan map and cross section were constructed along the proposed tunnel axis utilizing the core data and known geology of Rainier Mesa. The geologic interpretations were incorporated into the overall tunnel planning. During mining of the tunnel complex, geologists mapped the geology penetrated by the tunnels and constructed "as-built" maps and cross sections. Comparison of the predicted geology as interpreted from exploratory cores and the geology mapped along the tunnel alignment is shown in plan views (fig. 11). Locations of faults were based on both CI numbers and careful examination of core. In this example, faults cutting low-strength zeolitized ash-fall tuff exhibited CI values greater than 25 percent. The designation of rock units was determined from lithologic characteristics observed in the cores.

\section{COMPARISON OF THE CORE-INDEX AND ROCK QUALITY DESIGNATION SYSTEMS}

The CI and RQD techniques are similar in that both are relatively uncomplicated and fast procedures that estimate rock quality by discontinuity counts or spacing. The widely used RQD core-logging procedure (Deere, 1963; Deere and others, 1967) is a modified core-recovery method in which all pieces of sound core greater than 10 cm (4 in.) are counted as recovery. The sum of the lengths of the sound core are divided by the length

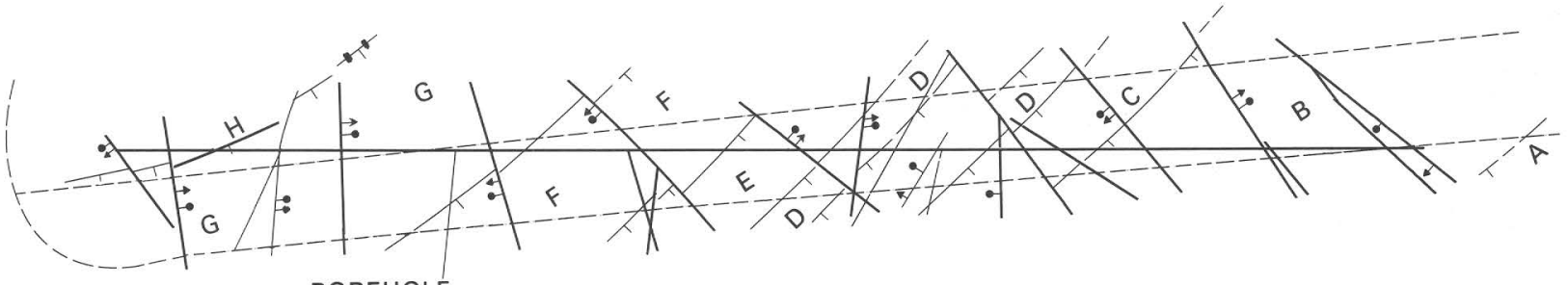

A

BOREHOLE

COLLAR OF BORE HOLE
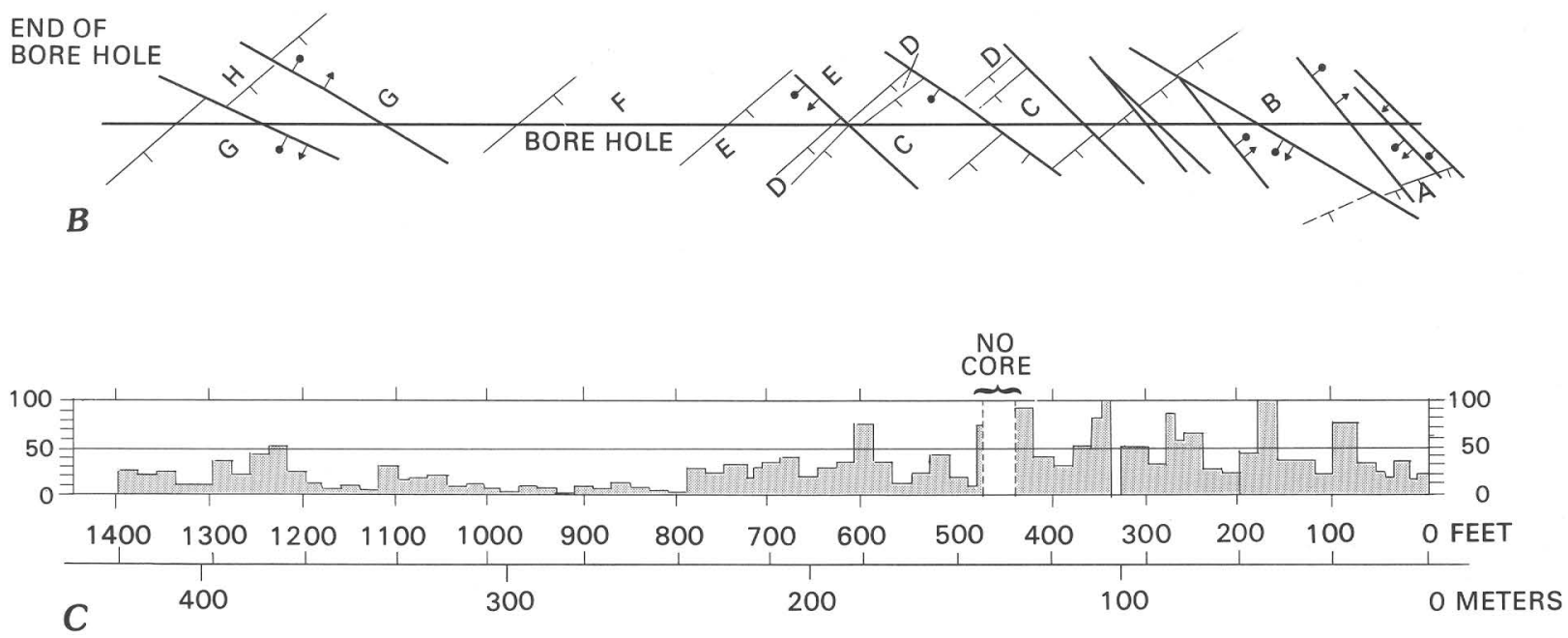

EXPLANATION
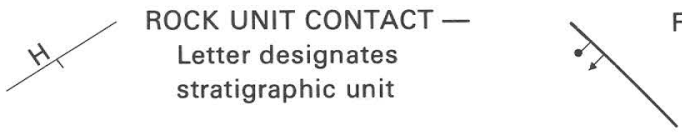

FAULT - Arrow designates

dip of fault, bar and ball shows direction

of displacement

Figure 11.-Comparison between a synthetic geologic plan $(B)$ constructed from horizontal borehole data $(C)$ using lithologic and core-index logging and the geologic plan $(A)$ mapped in a tunnel driven parallel to the exploratory boring. The' tunnel was mined in Tertiary ash-fall tuff below Rainier Mesa, Nevada Test Site. (Modified from Fairer and others, 1979.) 
of the drilled interval and a percent of recovered sound core is calculated. This recovery percentage is designated as the RQD and ranges from 0 for very poor rock to 100 for excellent rock.

Rock fragments less than $10 \mathrm{~cm}$ in the RQD procedure are considered to have been formed by jointing, faulting, close shearing, and weathering within the rock mass, and they are not included in the recovered-core measurements. Deleterious factors affecting rock quality, for example, weathered and alterated incompetent zones and closely spaced fractures, are, therefore, accounted for by not recording the smaller pieces. In this manner, a general estimate of engineering behavior of the rock mass is made.

One difference between the CI and RQD methods is that CI defines the form of fragmented rock in terms of lost core and broken pieces which may aid in interpreting the style of "weak" zones. For example, closely spaced fractured rock may appear as broken core, whereas soft highly weathered or altered rock may be washed from the core barrel and appear as lost core.

Another difference between the CI and RQD techniques is that the $\mathrm{CI}$ procedure, by recording the number of discontinuities in the greater-than$10-\mathrm{cm}$ sound core, provides information on the general occurrence of discontinuities as sources of planes of weakness throughout the rock mass. This can be an important consideration when working with very large underground openings where discontinuity spacing greater than $10 \mathrm{~cm}$, the RQD threshold value, may have to be considered as a stability factor.

Priest and Hudson (1976), from analysis of field-obtained scanline discontinuity data, indicated that a negative exponential distribution of discontinuity values is a good approximation to the true distribution patterns. The authors using the negative exponential distribution of discontinuity spacing values established a relation between a theoretical RQD and the average number of discontinuities per meter (fig. 12):

$$
\mathrm{RQD}=100 \mathrm{e}^{-0.1 \lambda}(0.1 \lambda+1)
$$

where 0.1 is the RQD threshold value of 0.1 and $\lambda$ is the average number of discontinuities per meter.

A result shown by the above equation and by the upper projection of the linear approximation of RQD with a conventional threshold value of $0.1 \mathrm{~m}$ (fig. 12) is that RQD is insensitive to a mean discontinuity spacing greater than $0.3 \mathrm{~m}(\lambda=3)$. Kulhawy (1978) discussed similar arguments. Core index, as previously mentioned, takes into account all discontinuities intersected along a borehole or scanline and, therefore, has sensitivity to a wider range of discontinuity spacing.

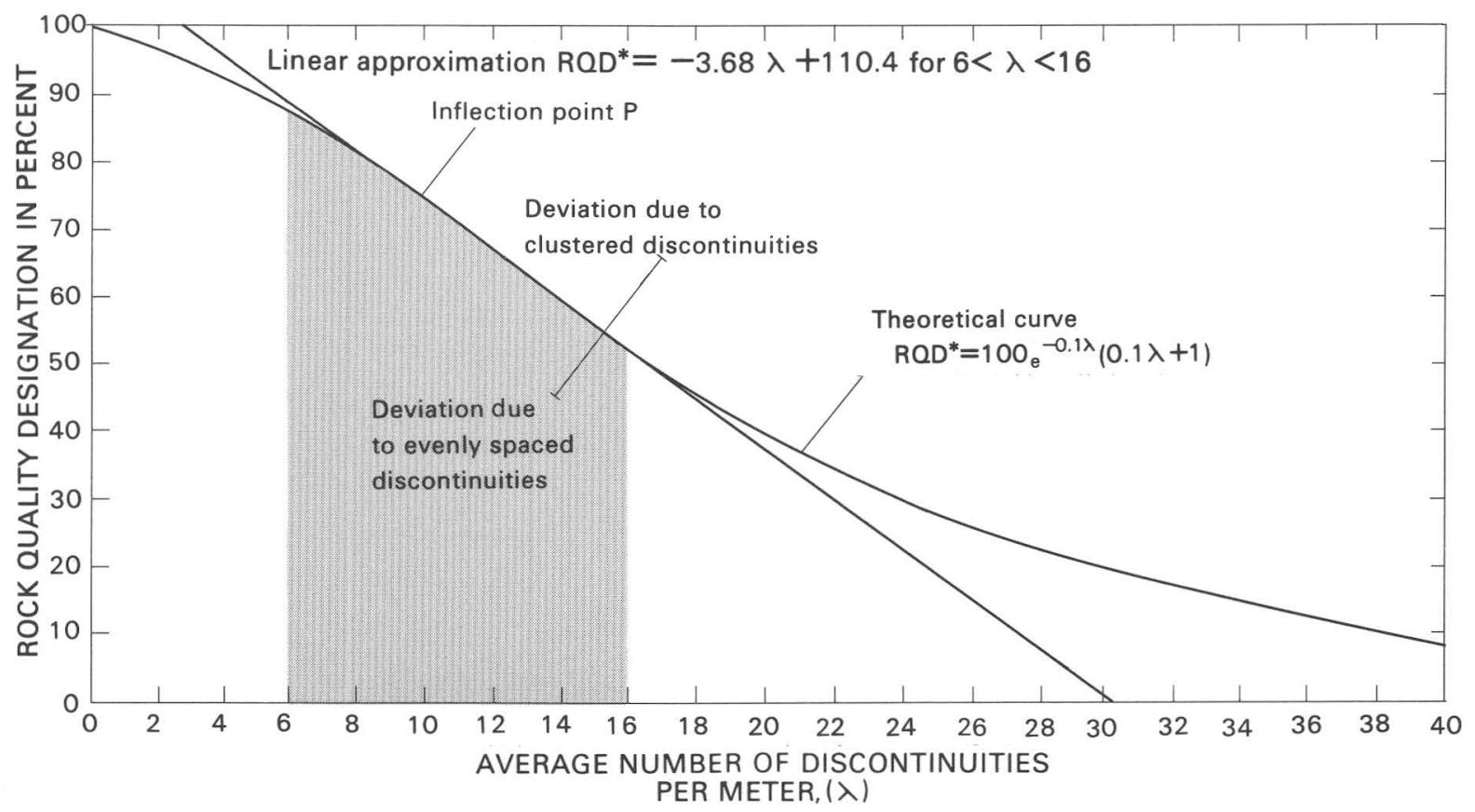

FIGURE 12.-Relation between Rock Quality Designation (RQD) and discontinuity frequency (Priest and Hudson, 1976). 


\section{CONCLUSIONS}

Core index (CI), a core logging system based upon frequency of natural discontinuities segmenting the core, has been in use by the USGS since 1968 as an evaluation tool for determining structural conditions related to engineered structures built in rock. The CI number, a quantity calculated from the logging procedure, provides an objective means for estimating rock quality in terms of its engineering properties and projecting geologic structures that may be encountered at the construction site. Correlation of rock-engineering conditions areally is possible between nearby exploratory boreholes and has been successfully used by the USGS at the NTS and other locales since inception of the technique.

The CI number is calculated from:

$$
\begin{aligned}
& \text { Core loss (m) + Broken core (m) } \\
& + \text { Number of discontinuities } \\
& \mathrm{CI}=\frac{\times 0.1(\mathrm{~m})}{\text { Drilled hole interval }(\mathrm{m})} \times 100 \\
& \mathrm{CI}=\frac{\begin{array}{l}
\text { Core loss }(\mathrm{ft})+\text { Broken core }(\mathrm{ft}) \\
+ \text { Number of discontinuities } \\
\times 0.3(\mathrm{ft})
\end{array}}{\text { Drilled hole interval }(\mathrm{ft})} \times 100
\end{aligned}
$$

A significant difference between the CI and RQD procedures is the inclusion of discontinuities as a separate parameter in calculating the CI number. This accounting of discontinuities makes the CI technique more sensitive to variations in rock quality, as compared to RQD, for average discontinuity spacings greater than $0.3 \mathrm{~m}$ based on the RQD threshold value of $10 \mathrm{~cm}$ (fig. 12) (Priest and Hudson, 1976).

Results of a study ranking physical property measurements of unconfined compressive strength, Young's modulus, shear modulus, bulk modulus, and compressional and shear velocities made on granitic cores against CI numbers showed decreasing values in these physical property measurements with increasing values of CI. Porosity measurements, as would be expected, showed increasing values with increasing values of $\mathrm{CI}$.

\section{REFERENCES CITED}

Barton, N., Lien, F., and Lunde, J., 1974, Engineering classification of rock masses for the design of tunnel support: Rock Mechanics, v. 6, no. 4, p. 189-236.

Bieniawski, Z. T., 1974, Geomechanics classification of rock masses and its application in tunneling: International Society for Rock Mechanics, 3d, Denver, Colorado, September 1974, Proceedings, v. 2A, p. 27-32.

Coates, D. F., 1964, Classification of rocks for rock mechanics: International Journal of Rock Mechanics and Mining Sciences, v. 1, no. 3, p. 421-429.

Deere, D. U., 1963, Technical description of rock cores for engineering purposes: Rock Mechanics and Engineering Geology, v. 1, no. 1, p. 16-22.

Deere, D. U., Hendron, A. J., Jr., Patton, F. D., and Cording, E. J., 1967, Design of surface and near-surface construction in rock, in Fairhurst, Charles, ed., Failure and breakage of rock: Symposium on Rock Mechanics, 8th, Minneapolis, Minnesota, September 1966, Proceedings: New York, American Institute of Mining, Metallurgy and Petroleum Engineers, p. 237-302.

Ege, J. R., 1968, Stability index for underground structures in granitic rock: Geological Society of America Memoir 110, p. 185-197.

1983, Use of joint planes in constructing a large hemispheric-shaped chamber in granitic rock: Association of Engineering Geology Bulletin, v. 20, p. 333-338.

Ege, J. R., Leavesely, G. H., Steele, S. G., and Weeks, J. B., 1978, Site evaluation for U.S. Bureau of Mines experimental oilshale mine, Piceance Creek Basin, Rio Blanco County, Colo rado: U.S. Geological Survey Open-File Report 78-390, 42 p.

Fairer, G. M., Townsend, D. R., Carroll, R. D., Cunningham, M. J., Muller, D. C., Healey, D. L., and Ellis, W. L., 1979, USGS investigations in connection with the Mighty Epic event, U12n.10 tunnel, Nevada Test Site: U.S. Geological Survey Report USGS-474-228, 189 p.; available only from U.S. Department of Commerce National Technical Information Service, Springfield, VA 22161.

Goodman, R. E., 1976, Methods of geological engineering: St. Paul, West Publishing Company, 472 p.

Kulhawy, F. H., 1978, Geomechanical model for rock foundation settlement: American Society of Civil Engineers Proceedings, Journal of the Geotechnical Engineering Division, v. 104, no. GT2, p. 211-227.

Obert, Leonard, and Duvall, W. I., 1967, Rock mechanics and the design of structures in rock: New York, John Wiley, 650 p.

Priest, S. D., and Hudson, J. A., 1976, Discontinuity spacings in rock: International Journal of Rock Mechanics and Mining Sciences and Geomechanics Abstracts, v. 13, no. 5, p. 135-148.

Terzaghi, K. C., 1946, Introduction to tunnel geology; Rock defects and loads on tunnel supports, in Proctor, R. V., and White, T. L., Rock tunneling with steel supports: The Commercial Shearing \& Stamping Co., Youngstown, Ohio, p. 15-99. 
